\title{
The Use of C-Ferns to Study Plasmolysis and Stomata Number
}

\author{
Kathleen A. Nolan ${ }^{1}$, Jia Ci Deng ${ }^{1}$, Joshlyn Mensah ${ }^{1}$, Jill E. Callahan ${ }^{2}$ and \\ Brandy Garrett-Kluthe ${ }^{2}$
}

\author{
${ }^{1}$ Department of Biology, Health Promotion, and Health Care Management, St. Francis College, \\ 180 Remsen St, Brooklyn NY 11201 USA \\ ${ }^{2}$ Department of Biology, St. Peter's University, 2641 Kennedy Blvd, Jersey City NJ 07306 USA \\ (knolan@sfc.edu: iiaci281@gmail.com; jmensah3@sfc.edu; jcallahan@saintpeters.edu; \\ bgarrettkluthe@saintpeters.edu)
}

Ceratopteris richardii (C-ferns) have been used to routinely study genetic crosses in our genetics laboratory courses. C-ferns produce two types of gametophytes: hermaphrodites and males. The hermaphrodites are heart-shaped flat, single-cell layer gametophytes producing both archegonia and antheridia and the males are club-shaped structures with antheridia only. When a concentrated $\mathrm{NaCl}$ solution (5\%) is added to these structures, plasmolysis can be observed in a matter of minutes. Since these plant forms are only a single-cell-layer thick, they offer a clearer, easier to view, model to observe and study plasmolysis in plants than the traditionally used Elodea leaves, which are two-cell layers thick. The sporophyte generation of $\mathrm{C}$-ferns is also only one-cell layer thick. These sporophytes make a rosette type clump and segments or pinnae from the developing fronds (pinnately compound leaves) can be easily plucked and make a neat flat sheet on a microscope slide on which plasmolysis (and/or turgor) can be observed. An additional mutant, the polka dot, "naturally" has clusters of chloroplasts in the center of the cell, so adding concentrated solutions does not affect the phenotype. Stomata are also easily observed in the sporophytes and are another way $\mathrm{C}$-ferns can be used in undergraduate laboratory projects. For example, students can test hypotheses about various conditions that would affect the number of open and closed stomata in C-ferns.

Keywords: C-fern, Ceratopteris richardii, plasmolysis, osmosis

Link to Original Poster File: https://doi.org/10.37590/able.v41.poster75

\section{Introduction}

Ceratopteris richardii is a small fern that is easy to culture in the laboratory. Scientists have used these ferns as a plant model to study genetics and the control of plant growth (Alifarag, 2012; Alongi et al, 2009; Bui et al., 2015; Spiro et al., 2004). C-fern spores can be seeded onto an iron-salt medium and will develop into gametophytes in approximately two weeks. The gametophytes are either hermaphrodites or male. The hermaphrodites can be flooded with water to facilitate sperm transfer from antheridia to the eggs contained in archegonia to enable fertilization. Sporophytes will then arise from the gametophytes.
The gametophyte tissue is th best to use for this experiment, which involves "plucking" a gametophyte from its agar medium, observing it under the microscope, adding concentrated sucrose or saline solutions, and then observing plasmolysis after ten minutes. We find that it is easier to observe plasmolysis in $\mathrm{C}$-ferns because they are only one cell layer thick, whereas the commonly used Elodea plants are two cell layers thick. Plasmolysis in Cferns could be the basis of inquiry-based experiments. When leaf cells plasmolyze, chloroplasts are pulled to the center as water is drawn out of the cells but it is difficult to observe plasmolysis in C-fern polka-dot mutants because a mutation causes chloroplasts to cluster (center of)in the leaf cells and thus cells appear not to change after 
adding sucrose or saline. The stomata in C-ferns are most easily observed in the sporophytes, providing an ideal model for students to conduct inquiry-based experiments on the response of stomata (open vs. closed) under various conditions.

Plasmolysis in C-ferns could also be a segue way into a broader discussion of osmosis in plants. For example, Anshori et al. (2018) tested salt tolerance and salt stress by studying the effects of various salt concentrations on rice varieties commonly grown in Indonesia. They are concerned that rising sea levels due to climate change will flood the paddies with sea water, creating a hypertonic environment harming the rice plants. Osmosis in wheat is well illustrated in excellent photos that depict the plasmolysis of root hairs exposed to various concentrations of mannitol (Volgger et al. 2010)

Another area worth investigating is the use of various "cryoprotectants" to preserve plants in a tank of liquid nitrogen. In the literature, we discovered that plants can be pre-treated with a mixture of solutions such as sucrose and glycerol that dehydrate the plant prior to immersion in liquid nitrogen in order that celldamaging ice crystals will not form (Volk and Caspersen, 2007).
Plasmolysis in plants has also been used to determine the level of tolerance in plants to toxic substances. Basile et al. (2012) explored the use of various aquatic plants as "phytoremediation agents" to clean up toxic water sources. They studied the levels of plasmolysis in plants grown in sub-lethal concentrations of various heavy metals to see how tolerant the plants were to these metals.

Another practical application is examined in Falade and Igbeka (2007) who provide a review of how osmotic dehydration is used in drying some of the foods we use. Barpete et al. (2016) found greater success in transforming cotton embryos with an insecticide gene if the embryos were first osmotically shocked by growing in hypertonic solutions of $\mathrm{KCl}$. This can enhance the growth of GM cotton plants that might provide stronger fibers and better oils, and are important world-wide economically. 


\section{Student Outline}

\section{Objectives}

Students will learn:

- How to observe C-fern gametophytes with first a dissection scope and then a compound scope, and identify that they are one-cell layer thick.

- How to add a hypertonic solution to the gametophytes and observe plasmolysis

- How to take pictures of their experiments and write cogent, descriptive, lab reports.

- $\quad$ To apply the knowledge learned from investigating plasmolysis and through readings in the references, to real-life situations.

\section{Methods and Data Collection}

1. Follow instructions with kit for growing $\mathrm{C}$-ferns. Usually, this will involve filling a vial of spores with $4 \mathrm{ml}$ of sterile water.

2. Pipet up and down with transfer pipet to keep spores suspended and evenly distributed. Re-suspend before seeding each plate.

3. Put required number of drops (3-5) on the small petri plate with $\mathrm{C}$-fern medium (your instructor will have either have prepared the plates for you ahead of time or might ask for your assistance in preparing them).

4. Let grow to the gametophyte stage for two weeks in the chamber (Fig. 1) under lamps in the windowsill. The C-ferns will grow a little faster with a temperature slightly above room temperature. Use the gametophytes for the plasmolysis experiment. You can let them "overgrow" into a sporophyte stage---the leaves of these will still work for the plasmolysis experiment.

5. Take the gametophyte of each variety of C-fern (wild type or polka dot), using a fine forceps, pin, or toothpick, place on a microscope slide, and observe and take photo. Note that this tissue is only one cell-layer thick.

6. Next, add a drop of distilled water to the edge of the cover glass and let it perfuse the sample. Observe and take photo. 7. Next, add a drop of desired solution ( $5 \%$ sucrose or saline) at the edge of the cover glass and let it perfuse the plant. Observe and take photos.

8. Wait two more weeks to see stomata on sporophytes that will develop from the gametophytes (your instructor may have some already at this stage). Focus up and down---they are in a slightly different focal plane. Count stomata per field of view. What percentage are open? Closed?

9. Write a lab report about all observations. Include photos you took with your phone or other cameras. Include in your discussion the importance of knowing about plasmolysis; use some of the references for examples. 


\section{Materials}

\section{Supplies and Sources}

\section{C-fern Options}

- Genetics in Action: Mendelian Genetics CFERN Kit

Item \# 156708 - contains wild type/ and polka dot heterozygote spores, media, small petri dishes, plastic tray and plastic cover OR

- Meet the C-FERN ${ }^{\circledR}$ Kit Item \# 156700 (You would have to order media separately) OR

- You can also order C-fern wild-type and polkadot spores and media separately

See the Carolina Biological website: for example:

$\mathrm{C}$ fern polka dot spores

C-FERN Spores, F1 Polka Dot, Pre-sterilized

Vial, Kit-Sized Item \# 156760

The Pre-sterilized (Kit-Sized) Vial inoculates 35

Petri dishes with $300+$ spores per dish.

C-fern agar: Item \# 156782 powdered media

that makes one liter of $\mathrm{C}$-fern agar.

- For a list of the 11 micro- and macronutrients required to make this media, in addition to water and agar see:

https://s10.lite.msu.edu/res/msu/botonl/b online/ library/cfern/cfern.bio.utk.edu/manual/cfmnutrie ntpreparation.html

- Small petri dishes for $\mathrm{C}$-fern media

- Transfer pipets

- Tray with clear plastic cover (provided by Carolina Biological) OR soft vinyl cooler that is open to light

- Lamps with any type of white-light bulb

- Dissection scopes

- Compound scopes

- Watchman forceps (or pins or toothpicks) for removing gametophytes from plates

- Microscope slides

- Cover glasses

- $5 \%$ saline and/or sucrose

- Distilled water

- Cameras or phones for documenting

\section{Notes for the Instructor}

See Figure 1 for the set-up of the plates. The top photo is the complete set-up, complete with the C-ferns in the petri plates with the media, beakers that act as humidifiers, plastic cover, and lamps. The bottom photo shows the set-up with the plastic cover removed. It is important to emphasize to the students that they need to resuspend the spores EACH TIME they plate out three drops; otherwise, some plates will have too many gametophytes and others will have none. (An optional activity is to have the students observe spores under the microscope and take pictures of those.)

\section{Selected Results}

Students were able to observe plasmolysis more readily with $\mathrm{C}$-fern gametophytes than with Elodea. The polka-dot mutants, however, yielded no change. Students were also able to count stomata in a field of view and note numbers of closed and open stomata. They were required to suggest additional experiments that they could conduct using this model in their lab reports.

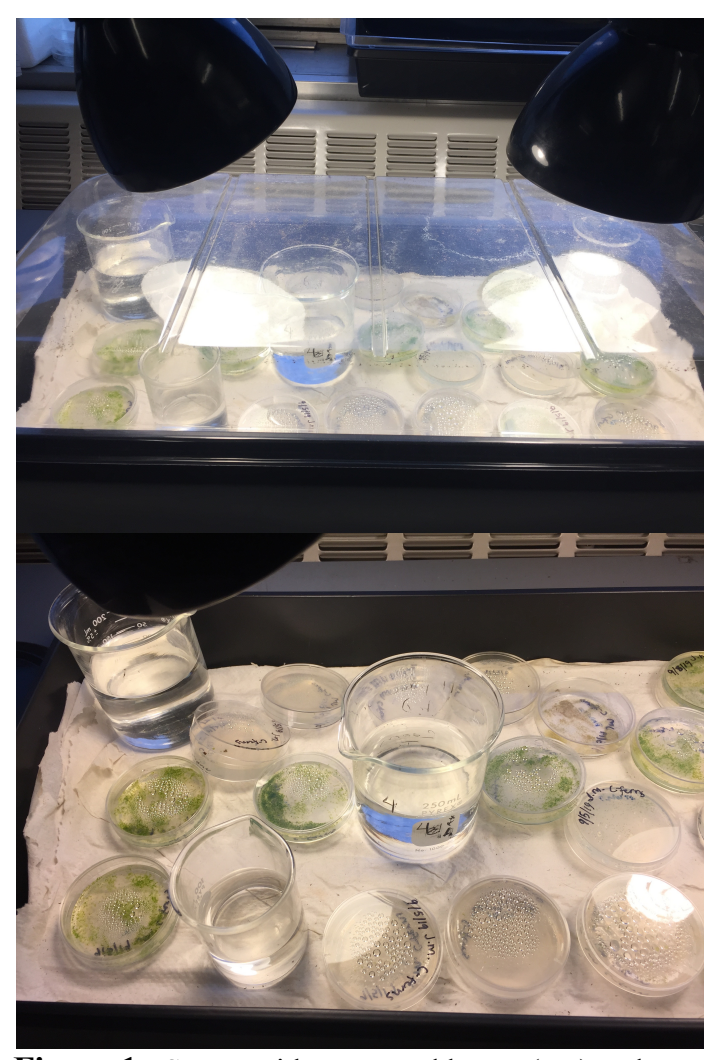

Figure 1. Set-up with cover and lamps (top) and removed to show plates with C-ferns (bottom). Photo credit: Kathleen A. Nolan 


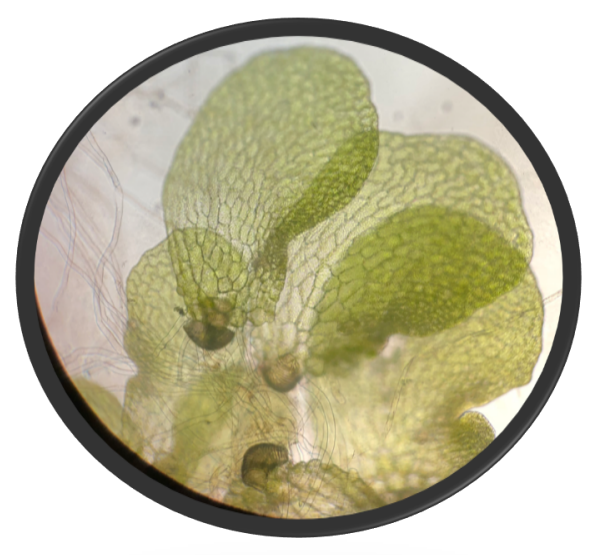

Figure 2. Male C-Fern gametophytes showing single-cell layer (40X). Photo credit: Joshlyn Mensah

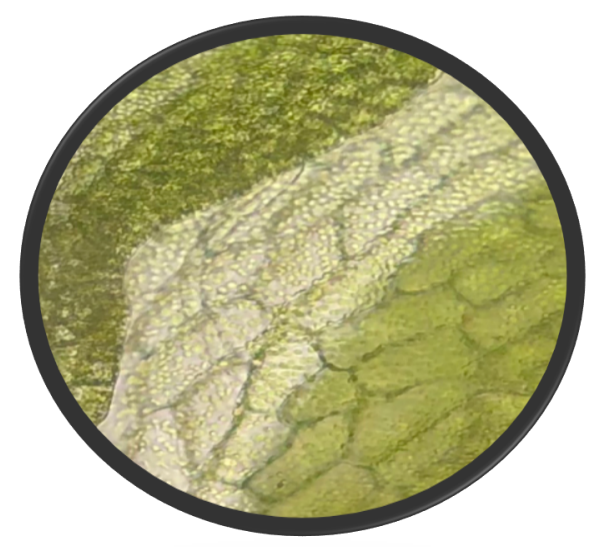

Figure 3. C-fern gametophyte in water, depicting an even distribution of chloroplasts $(400 \mathrm{X})$. Photo credit: Joshlyn Mensah

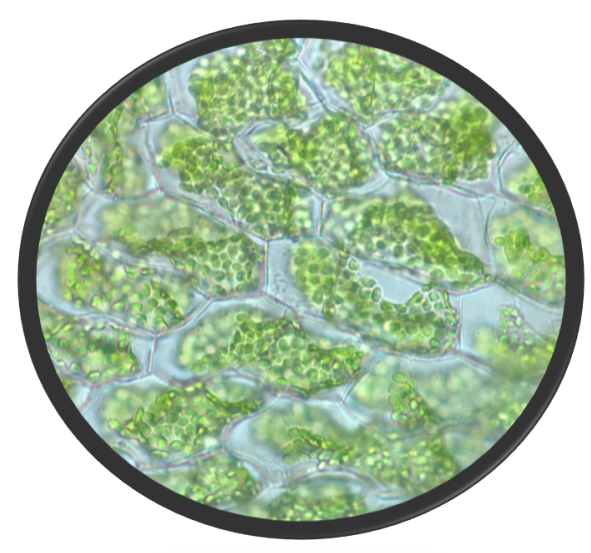

Figure 4. C-fern gametophyte after $10 \mathrm{~min}$ in $5 \% \mathrm{NaCl}$. Note that cells have shortened and gotten fatter, and the chloroplasts are clumped in the middle of the cell, indicating plasmolysis. Photo credit: Joshlyn Mensah

\section{Discussion}

The discovery of the C-fern as a tool to demonstrate plasmolysis was serendipitous. I (Nolan) was examining the gametophyte under the microscope and noticed that it was one-cell layer thick. I added some concentrated sucrose, and voila plasmolysis occurred! With student researchers, we were able to demonstrate that this phenomenon can only easily be observed with the wild type, rather than the polka dot mutant form of C-fern. Both the gametophyte (preferable because it forms first) and the sporophyte can be used. We have introduced this exercise into our second semester General Biology laboratory, in which we have plenty of C-ferns that have been grown by the genetics class to study the genetics of this model organism. Even though the students have learned about plasmolysis during the fall semester, they are then able to revisit this topic in the spring, where it is reinforced. In addition, the students can observe the gametophytes and subsequent sporophytes to aid in learning about the alternation of generations of plants. Students can also observe stomata in these plants, and conditions can be introduced in which students can then take pictures and count stomata, and, moreover, note whether they are open or closed. Another experiment that we did 
not try was rehydrating the plants as Proctor (2007) was able to successfully do with several moss species. We are devising assessments to test the efficacy of using this system to teach about plasmolysis, the importance and utility of stomata, and life cycles in plants.

\section{Cited References}

Alifarag A. 2012. Isolation and analysis of Ceratopteris richardii Antheridiogen C. Student thesis at Baruch College, City University of New York (CUNY) CUNY Academic Works. 66 pp. https://academicworks.cuny.edu/bb_etds/2

Alongi DA, Hill JP, Germino MJ. 2009. Opportunistic heterotrophy in gametophytes of the homosporous fern Ceratopteris richardii. Botany. 87(8):799-806.

Anshori, MF, Purwoko, BS, Dewi, IS, Ardie, SW, Suwarno, WB, SafitrI, H. 2018, Determination of selection criteria for screening of rice genotypes for salinity tolerance. SABRAO Journal of Breeding \& Genetics. 50(3):279-294. http://search.ebscohost.com/login.aspx?direct=tr ue $\& \mathrm{db}=\mathrm{a} 9 \mathrm{~h} \& \mathrm{AN}=132279753 \&$ site $=$ ehost live $\&$ scope $=$ site

Barpete S, Bakhsh A, Anayol E, Özcan SF, Oğuz MC, Karakoç ÖC, Özcan S. 2016. Inducing osmotic stress leads to better genetic transformation efficiency in cotton (Gossypium hirsutum L.). Turkish Journal of Biology. 40(4):826-836. $<$ http://search.ebscohost.com/login.aspx?direct $=\mathrm{t}$ rue $\& \mathrm{db}=\mathrm{a} 9 \mathrm{~h} \& \mathrm{AN}=116888385 \&$ site $=$ ehost live \&scope $=$ site $>$

Basile A, Sorbo S, Conte B, Cobianchi RC, Trinchella F, Capasso C, Carginale V. 2012. Toxicity, accumulation, and removal of heavy metals by three aquatic macrophytes. International Journal of Phytoremediation [Internet]. 14(4):374-87. $\mathrm{http}: / /$ search.ebscohost.com/login.aspx?direct=tr $\mathrm{ue} \& \mathrm{db}=\mathrm{a} 9 \mathrm{~h} \& \mathrm{AN}=67651745 \&$ site $=$ ehost live \&scope $=$ site-

Bui LT, Cordle AR, Irish EE, Cheng CL. 2015. Transient and stable transformation of Ceratopteris richardii gametophytes. BMC Research Notes. 8(1):1-10.
Falade KO, Igbeka JC. .2007. Osmotic dehydration of tropical fruits and vegetables. Food Reviews International. 23(4):373-405. $<\mathrm{http} / /$ search.ebscohost.com/login.aspx?direct=t rue $\& d b=a 9 h \& A N=26706315 \&$ site $=$ ehostlive \&scope $=$ site $>$

Proctor MCF, Ligrone R, Duckett JG. 2007. Desiccation tolerance in the moss Polytrichum formosum: physiological and fine-structural changes during desiccation and recovery. Annals of Botany 99 (1):75-93. https://doi.org/10.1093/aob/mcl246

Spiro MD, Torabi B, Cornell CN. 2004. Cytokinins induce photomorphogenic development in darkgrown gametophytes of Ceratopteris richardii. Plant \& Cell Physiology. 45(9):12521260.

Volgger, M. Lang, I, Ovečka, M \& Lichtscheidl, I. 2010. Plasmolysis and cell wall deposition in wheat root hairs under osmotic stress. Protoplasma. 243(14):51-62. doi: 10.1007/s00709-009-0055-6.

Volk GM, Caspersen AM. 2007. Plasmolysis and recovery of different cell types in cryoprotected shoot tips of Mentha x piperita. Protoplasma 231(3-4): 215-26. doi:10.1007/s00709-007-0251-1.

\section{Acknowledgments}

Thanks to the Genetics classes at St. Francis College for initially growing C-fern gametophytes, and Leah Kovenat, our laboratory supervisor, who orders all our supplies and assists with the experimental set-ups.

\section{About the Authors}

Kathleen A. Nolan, Ph.D. is a professor of biology and Chair of the Biology, Health Promotion, and Health Care Management Department at St. Francis College. She has been a long-time ABLE member and has presented numerous major and mini- workshops at ABLE conferences. She is interested in a wide variety of topics, including fish population genetics, animal vocalizations, and biology laboratory education.

Jia-Ci Deng conducted some of this work while she was a student at Midwood H.S. She is now a biology major at the State University of New York (SUNY) Stonybrook.

Joshlyn Mensah is a biology major at St. Francis College that assisted with the experiment and protocol.

Jill E. Callahan, Ph.D. is an associate professor of biology and Chair of the Biology Department at St. Peter's University. She teaches and coordinates parasitology, 
honors general biology lecture and lab, microbiology lecture and lab, anatomy and physiology, and research methods. She obtained a B.A. in Biology from St. Anselm College and a Ph.D. from Virginia Commonwealth University. She is very interested in studying infectious disease, including bacterial biofilms and parasites, and bioacoustics.

Brandy Garrett-Kluthe, Ph.D. is an assistant professor of biology and a botanist at St. Peter's
University. Her research is focused on the introduced Eucalyptus tree and the impacts it has had on the environment and society in the country of Kenya. Dr. Kluthe is currently working on allopathic chemicals and the mycorrhizal fungi associated with introduced species. She is very interested in laboratory education and inquirybased learning. 


\section{Mission, Review Process \& Disclaimer}

The Association for Biology Laboratory Education (ABLE) was founded in 1979 to promote information exchange among university and college educators actively concerned with teaching biology in a laboratory setting. The focus of ABLE is to improve the undergraduate biology laboratory experience by promoting the development and dissemination of interesting, innovative, and reliable laboratory exercises. For more information about ABLE, please visit http://www.ableweb.org/.

Advances in biology laboratory education is the peer-reviewed publication of the conference of the Association for Biology Laboratory Education. Published articles and extended abstracts are evaluated and selected by a committee prior to presentation at the conference, peer-reviewed by participants at the conference, and edited by members of the ABLE Editorial Board. Published abstracts are evaluated and selected by a committee prior to presentation at the conference.

\section{Citing This Article}

Nolan KA, Deng JC, Mensah J, Callahan JE, Garrett-Kluthe B. 2020. The use of C-ferns to study plasmolysis and stomata number. Article 74 In: McMahon K, editor. Advances in biology laboratory education. Volume 41. Publication of the 41st Conference of the Association for Biology Laboratory Education (ABLE). https://doi.org/10.37590/able.v41.art75

Compilation (C) 2020 by the Association for Biology Laboratory Education, ISBN 1-890444-17-0. All rights reserved. No part of this publication may be reproduced, stored in a retrieval system, or transmitted, in any form or by any means, electronic, mechanical, photocopying, recording, or otherwise, without the prior written permission of the copyright owner.

ABLE strongly encourages individuals to use the exercises in this volume in their teaching program. If this exercise is used solely at one's own institution with no intent for profit, it is excluded from the preceding copyright restriction, unless otherwise noted on the copyright notice of the individual chapter in this volume. Proper credit to this publication must be included in your laboratory outline for each use; a sample citation is given above. 